\title{
Making sense of the numbers
}

\section{Civil claims against the SAPS}

\author{
Gwen Dereymaeker* \\ g.dereymaeker@gmail.com \\ http://dx.doi.org/10.4314/sacq.v54i1.3
}

In recent years reports have increasingly pointed to the mounting quantum of claims for civil damages faced by the South African Police Service (SAPS). A close analysis of the publicly available data shows that increasingly large amounts of claims are filed against the SAPS, but that most of these claims are finalised without the SAPS, being held financially liable. However, the backlog of claims is ever mounting and needs to be addressed more proactively. It appears that factors external to police officials' behaviour do not explain the increase in claims. The reasons are more likely related to unlawful police behaviour, and in particular police violence.

The South African Police Service (SAPS) has in recent years reported a substantial annual increase in civil claims filed for damages as a result of actions or omissions by its officials, and an even larger increase in claims pending. The 2014/15 SAPS annual report showed that pending claims stood at over R26 billion, which is equivalent to over a third of the SAPS budget.

The minister of police said in 2014 that he was not satisfied with the number of civil claims made against the SAPS, and that increased police professionalism, coupled with compliance with the law and the relevant policies in place, should reduce the amount of claims made. ${ }^{1}$ The minister of police also instructed the national commissioner to address the issue of mounting civil claims, and the national commissioner instructed SAPS officials to comply with the law when making arrests or detaining someone, in order to avoid civil claims. ${ }^{2}$

The 2014/15 SAPS annual report reiterates that the SAPS regards the causes behind civil claims as

\footnotetext{
* Gwen Dereymaeker is a researcher at the Civil Society Prison Reform Initiative, a project of the Dullah Omar Institute for Constitutional Law, Governance and Human Rights at the University of the Western Cape.
}

a lack of compliance with standing orders and a high rate of unlawful arrests and detentions. ${ }^{3}$ The 2014/15 annual report adds that '[c]itizens have become more aware of their rights and are enforcing them vigorously'. ${ }^{4}$

This article attempts to clarify the issue of civil claims against the police. After outlining the legal basis for vicarious liability of the state for actions of police officials, the article analyses data from SAPS annual reports (from 2007/08 to 2014/15) to better understand the trends in relation to claims being made, paid out, reduced or cancelled. The last section of the article offers an explanation for these trends.

\section{State liability for individual police action}

This section outlines the legal basis for filing claims for damages against the minister of police, and the potential individual financial liability of police officials responsible for the actions or omissions that resulted in such claims. Although the article focuses on claims made against and payments made by the state, there exists a regulatory basis in terms of which individual officials responsible for unlawful 
behaviour that resulted in payment can be held personally liable.

Under the South African civil law of delict, any person who 'wrongfully and culpably causes damage or harm to another' through an act or omission is liable for compensation. ${ }^{5}$ Therefore, if a police official voluntarily or negligently commits an act or omits to perform an act and by (not) doing so causes another person's rights to be infringed, he or she can be held directly liable to pay compensation. However, under the State Liability Act, the state can also be held vicariously liable for any wrongful act committed by its officials in the course of their employment. ${ }^{6}$ There is an academic debate about the extent and adequacy of the common law of delict relating to state liability, and how it is applied by the courts, but this will not be addressed here. (See also the case note by Heidi Barnes in SACQ 47.)

The Public Finance Management Act states that the National Treasury Regulations or Instructions must address 'the settlement of claims by or against the State' and 'the recovery of losses and damages'. ${ }^{8}$ Regulation 12 of the Treasury regulations regulates the state's liability for acts and omissions by its officials. As a principle, the regulations grant 'state protection' to public officials, in that any state institution must accept liability 'for any loss or damage suffered by another person, which arose from an act or omission of an official'. ${ }^{9}$ The individual official cannot be held directly liable for acts committed in the course of his or her employment, if there is a causal link between the wrongful act or omission of the official and the loss or damage caused. ${ }^{10}$ This explains why the state (in this case, the minister of police) is most often cited as a defendant in civil claims cases. Also, the financial resources available to the minister are vast in comparison to the often meagre financial resources of the individual officials responsible for the wrongful behaviour.

However, the regulations also contain a series of exceptions where the state will not provide protection to the official and should, in theory, not be held liable or should recover the compensation paid to the victim from the official. ${ }^{11}$ These exceptions include any criminal act committed by an official; intentionally exceeding one's powers; or acting recklessly or intentionally. ${ }^{12}$

In practice, the relevant provisions of the Treasury regulations requiring accounting officers to recover expenses from negligent, reckless, power-abusing or criminal officials (such as those committing unlawful arrests, unlawful or irregular search and seizures, police detention beyond the 48-hours rule, or general unlawful police behaviour) are not being implemented. In a July 2013 parliamentary reply, the minister of police indicated that no police member had been '[disciplinarily] charged for misconduct as a result of civil claims against the SAPS'. ${ }^{13}$ Despite committing, in the same parliamentary reply, to developing recommendations to hold individual police officials liable, these never surfaced in the public domain.

\section{Civil claims against SAPS: understanding the data}

Annually, the SAPS reports on the amount of contingent liabilities pending against the Department of Police. ${ }^{14}$ Contingent liabilities are potential expenses dependent on the outcome of an event, such as a court ruling or an out-of-court settlement. In other words, there is no certainty in these cases that any money will be paid out. Each annual report lists contingent liabilities, the largest proportion of which are claims for civil damages made by individuals against the minister of police for alleged unlawful actions by police officials. (This article only focuses on civil claims.)

The minister of police has provided additional information on civil claims in written replies to parliamentary questions in 2013 and 2015, including on the number of claims incurred by the SAPS (annual reports only contain information on the total amounts claimed). However, the information provided in the annual reports does not match the information provided in parliamentary replies. ${ }^{15}$ Since information from annual reports is audited by the auditor-general, this article almost exclusively relies on annual reports.

The SAPS reports on claims incurred over each financial year, claims cancelled or paid out during the year (i.e. either following a court finding that the SAPS was either liable or not liable, an out-of-court settlement or a claim that was withdrawn), and a 
closing balance (i.e. all claims that remain pending against the SAPS at the end of each financial year, which constitutes an accumulative figure of all claims pending from that financial year and from previous financial years). ${ }^{16}$ These three categories of liabilities (incurred, finalised and pending) will be examined in the following sections. Both amounts originally reported on and amounts adjusted to inflation (at March 2015 rand value) will be used. ${ }^{17}$ The latter is how much a particular amount would be worth if adjusted to the value of the rand in March 2015, considering annual inflation rates. Amounts adjusted to inflation provide a more accurate estimate of the value of each figure, as each amount is adjusted to the value of the rand on the same date.

Important to note is that not all civil claims are for actions that can be qualified as gross human rights violations by police officials. The categories of civil claims are typically the following: vehicle accidents, legal fees, damage to property and damage to state property, assault, police actions (a 'catch-all' category that includes unlawful arrests), shooting incidents, and a large 'other' category that includes all claims that have yet to be classified. The 'assault', 'police actions' and 'shooting incidents' categories are those that raise the most questions about the SAPS's compliance with basic constitutional and legal prescripts and general ethical conduct.

During the period 2007/08 to 2014/15, an average of $80 \%$ of all claims made annually, an average of $86 \%$ of all claims pending at the end of a financial year, and an average of $86 \%$ of all payments made, fell into these three categories. Therefore, assaults, shooting incidents and other police actions (including unlawful arrests) constitute the majority of claims the department has to deal with.

For the sake of conciseness, this article will only deal with overall civil claim figures, and will not examine in detail the claims made or paid out in these three specific categories.

\section{Incurred liabilities}

Table 1 outlines the total claims for civil damages incurred by the SAPS annually between 2007/8 and 2014/15, as well as all claims that remain pending at the end of the financial year. ${ }^{18}$ The figures used are both the original values reported on, and those adjusted to the rand value of March 2015.

Figure 1 on the next page reflects on the numbers contained in Table 1 and shows the increase in claims made annually against the SAPS until 2011/12. Between 2011/12 and 2013/14 there was a slight reduction, followed by a sharp increase in the last financial year. The top line shows the accumulative claims pending against the SAPS that have yet to be finalised.

Between the 2007/08 and 2014/15 financial years, claims made annually against the SAPS increased by $533 \%$ if considering the original rand value, or $313 \%$ if adjusted to the same rand value (a more accurate figure). Claims made since the $2011 / 12$ financial year decreased for two years, then sharply increased in the past financial year, and stood at R9.6 billion in

Table 1: Total claims incurred in one financial year and pending at the end of a financial year, at original value and at current rand value (March 2015), 2007/08 to 2014/15

\begin{tabular}{|c|c|c|c|c|}
\hline Financial year & $\begin{array}{c}\text { Total amounts } \\
\text { incurred, at original } \\
\text { value ('000) }\end{array}$ & $\begin{array}{c}\text { Total amounts } \\
\text { incurred, at March } \\
2015 \text { rand value } \\
\end{array}$ & $\begin{array}{c}\text { Total amounts } \\
\text { pending, at original } \\
\text { value ('000) }\end{array}$ & $\begin{array}{c}\text { Total amounts } \\
\text { pending, at March } \\
2015 \text { rand value }\end{array}$ \\
\hline $2007 / 08$ & R 1515597 & R 2320158 & R 5290512 & R 8099003 \\
\hline 2008/09 & R 3266230 & R 4498535 & R 7916554 & R 10903365 \\
\hline $2009 / 10$ & R 2522463 & R 3262117 & R 8098669 & R 10473418 \\
\hline $2010 / 11$ & R 3692193 & R 4600042 & R 10489004 & R 13068077 \\
\hline $2011 / 12$ & R 7174091 & R 8464092 & R 14492322 & R 17098243 \\
\hline $2012 / 13$ & R 6976537 & R 7794522 & R 18322416 & R 20470683 \\
\hline 2013/14 & R 5934019 & R 6266324 & R 20544283 & R 28367826 \\
\hline $2014 / 15$ & R 9589568 & R 9589568 & R 26918721 & R 26918721 \\
\hline TOTAL & R 40670698 & R 46795359 & N.A. & N.A. \\
\hline
\end{tabular}


Figure 1: Total amount of claims incurred per financial year and total amount of accumulative pending claims, at current rand value (March 2015), 2007/08 to 2014/15

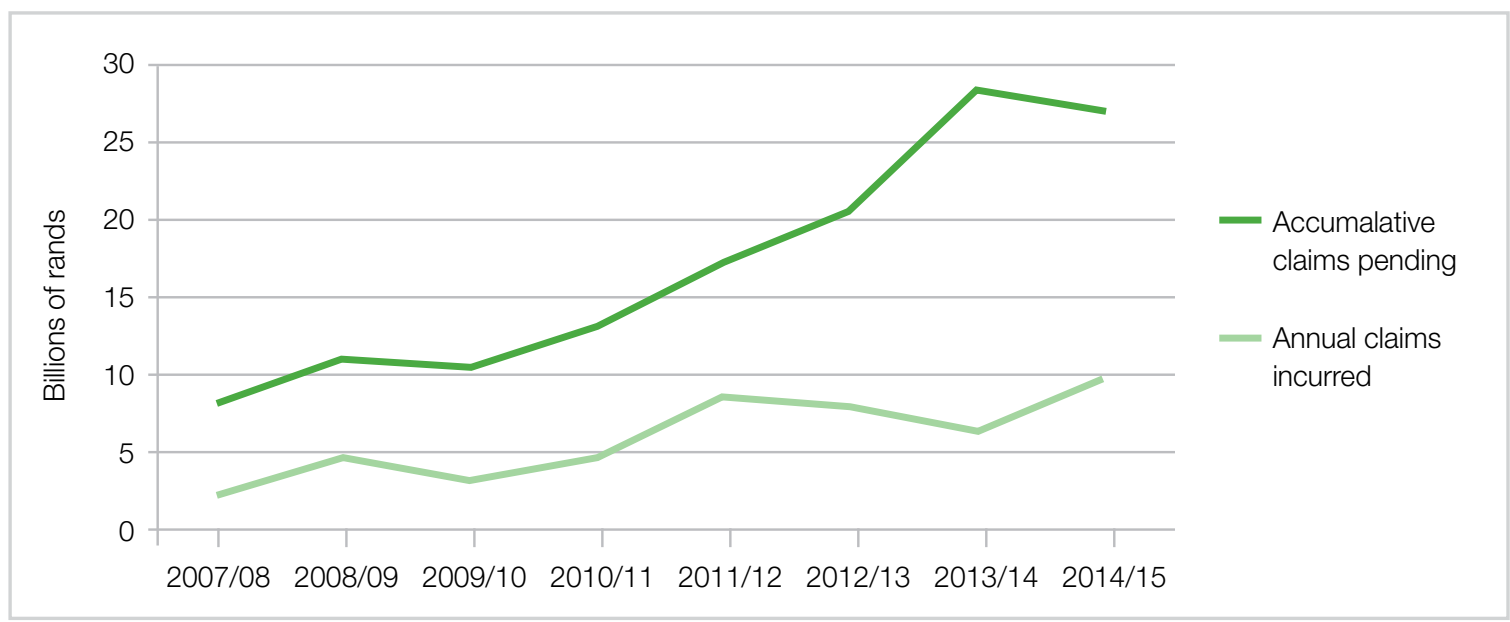

2014/15. The as-yet undisclosed amounts claimed by the Marikana victims were filed in August 2015 and are therefore not reflected in this article. In total, over the eight-year period analysed here, claims totalling R46.8 billion have been made against the police, at adjusted rand value. ${ }^{20}$ These worryingly high figures indicate a public perception that police behaviour is too often not compliant with laws and regulations and worthy of a civil claim.

A large portion of claims made in one financial year are not 'dealt with', or finalised, in the same financial year, creating an ever-mounting backlog of claims pending against the SAPS. These are the amounts often referred to in the media, ${ }^{21}$ and are reflected in the third and fourth columns of Table 1. These pending claims also represent an ever-increasing portion of the total SAPS budget. Indeed, pending claims at the end of $2007 / 08$ represented $16 \%$ of the SAPS budget, whereas the $2014 / 15$ overall accumulative contingent liability for civil claims represented $37 \%$ of the SAPS annual budget. ${ }^{22}$ As will be shown in the next section, most of these claims will not result in payment, and the SAPS does not actually make provision for payment of all amounts claimed. ${ }^{23}$ However, the fact that accumulative pending claims represent such a large segment of the SAPS budget has an impact on the public perception of the behaviour of SAPS officials, since the general assumption is that most if not all claims pending will result in payment by the SAPS.
One must also question whether the SAPS intends to finalise claims as swiftly as possible.

When attempting to outline the reasons behind the large volume of claims pending, the SAPS has focused on the procedural challenges affecting it. The SAPS has explained that each claim had to follow due process (knowing that a trial takes on average three years to complete, and that pending claims therefore stay on the SAPS books for that duration), that pending claims are claims only, that the amounts claimed are decided by the plaintiff or their legal representative, which are, according to the SAPS (and confirmed by the analysis below) 'very much inflated', and that there is no certainty regarding the outcome of the claim, which may or may not result in a liability for the SAPS. ${ }^{24}$ These may explain the reasons for the ever-growing accumulative pending claims, but not the reasons for the claims having been made in the first place.

The principal reason for the increasing pending claims is the length of court proceedings. A timeand cost-effective process to circumvent slow court proceedings would be to enter into an out-of-court settlement. ${ }^{25}$ The SAPS does enter into a number of out-of-court settlements to settle civil claims. However, no information is available on the SAPS's possible strategy to go this route (with the notable exception of the SAPS's public efforts to prefer an out-of-court settlement with the Marikana victims), ${ }^{26}$ 
especially when the outcome of the case, based on the evidence available and similarity with previous cases, will manifestly be in favour of the plaintiff. Also, the SAPS may struggle to reach out-of-court settlements as plaintiffs prefer to wait for a court ruling, hoping to obtain more substantial damages than through an out-of-court settlement - this despite the length of, and legal fees associated with, court proceedings.

\section{Claims finalised}

A claim is finalised following a court ruling, an outof-court settlement or its withdrawal by the plaintiff. Court rulings in favour of the plaintiff and out-of-court settlements can result in payment for the full amount originally claimed, or for a reduced amount.

Table 2 shows that the vast majority of claims that are finalised result in the claim being cancelled or reduced, i.e. in the plaintiff withdrawing the claim, in a court finding that the SAPS was not liable for the amounts claimed or was liable for a lower amount, or in a settlement for an amount lower than what was originally claimed. ${ }^{27}$

Adjusting all amounts to the rand value of March 2015, Table 2 shows that R30 billion was finalised over the eight-year period analysed in this article, of which R1.2 billion resulted in a liability for the SAPS (i.e. a payment by the SAPS) and R29 billion resulted in non-payment (either the claim was withdrawn, or the SAPS was not held liable, or was ordered to pay less than originally claimed, or an agreement was reached to pay less than originally claimed). Over the eight-year period under review, only $4 \%$ of all amounts claimed that were finalised resulted in a payment by the SAPS.

Comparing the data from Table 1 and Table 2, only $65 \%$ of all claims made against the SAPS between 2007/08 and 2014/15 were finalised, whether the outcome was that of a liability for the SAPS or not. The further $35 \%$ of claims remain pending. However, in 2014/15 and for the first time in the period under review, a similar quantum of claims was finalised and made, indicating that the SAPS appears to be attempting to address the backlog of cases.

The amounts paid out annually have also steadily increased. They increased by 338\% between 2007/08 and 2014/15, a slightly higher increase than the claims made annually (313\%, as indicated above).

Figure 2 on the next page summarises the total amounts finalised. This chart shows that, at current rand value and with the exception of 2008/09, 2010/11 and 2014/15, amounts finalised were in a similar value range every year, while claims incurred kept increasing (see Figure 1). More claims were incurred than claims finalised, resulting in the backlog of pending claims accumulating year after year, as identified above. This said, 2014/15 was an obvious exception, as a similar amount of claims was finalised and incurred. However, based on the available data, it is impossible to tell whether the SAPS decided in that year to finalise all claims that were without merit and to focus on claims with merit (those that remain

Table 2: Total amounts finalised and total amounts paid out, at original value and at current rand value, $2007 / 08$ to $2014 / 15$

\begin{tabular}{|c|c|c|c|c|}
\hline Financial year & $\begin{array}{c}\text { Total amounts } \\
\text { finalised, at original } \\
\text { value ('000) }\end{array}$ & $\begin{array}{l}\text { Total amounts } \\
\text { finalised, at current } \\
\text { rand value ('000) }\end{array}$ & $\begin{array}{c}\text { Total amounts paid } \\
\text { out, at original value } \\
\text { ('000) }\end{array}$ & $\begin{array}{c}\text { Total amounts paid } \\
\text { out, at current rand } \\
\text { value ('000) }\end{array}$ \\
\hline $2007 / 08$ & R 2591851 & R 3967746 & 38207 & 58489 \\
\hline $2008 / 09$ & R $\quad 960857$ & R 1323376 & 57403 & 79060 \\
\hline $2009 / 10$ & R 2952198 & R 3817862 & 79451 & R 102748 \\
\hline $2010 / 11$ & R $\quad 746164$ & R 929633 & 85605 & $R \quad 106654$ \\
\hline $2011 / 12$ & R 2818726 & R 3325572 & R 105960 & R 125013 \\
\hline $2012 / 13$ & R 3021501 & R 3375766 & R 187132 & R 209073 \\
\hline $2013 / 14$ & R 3712152 & R 3920032 & R 251192 & R 265259 \\
\hline $2014 / 15$ & R 9534319 & R 9534319 & R 256188 & R 256188 \\
\hline TOTAL & R 26337768 & R 30194307 & R 1061138 & R 1202484 \\
\hline
\end{tabular}


Figure 2: Total amounts finalised, whether resulting in a liability for the SAPS (payments made, dark green) or resulting in the SAPS not being liable (amounts reduced or cancelled, light green), at March 2015 rand value, 2007/08 to 2014/15

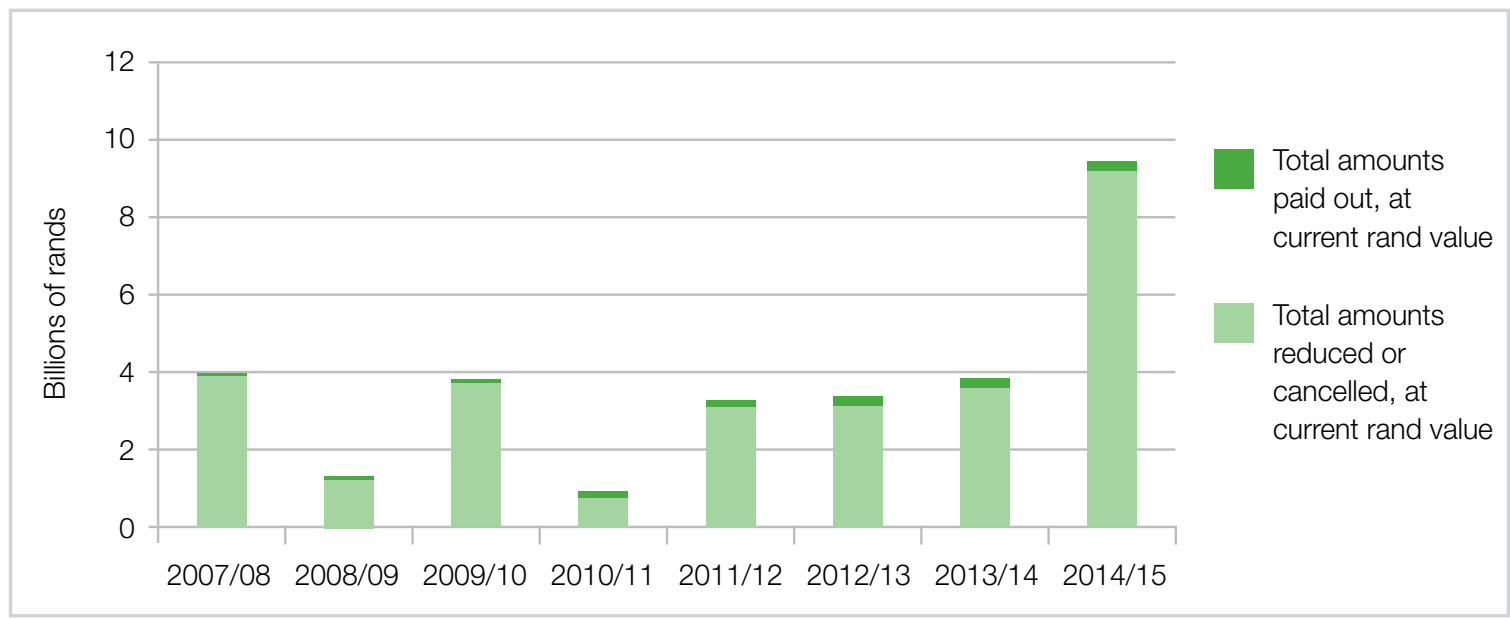

pending) going forward, or whether the claims finalised in the last financial year are any different to the claims that remain pending. It is therefore impossible to predict whether the claims that remain pending will result in payment by the SAPS or not.

\section{Legal fees to defend civil claims to be added to damages awarded}

The figures outlined above only focused on damages claimed and awarded. They exclude the additional cost of legal fees incurred by both the plaintiff and the SAPS. Like any other government department, the SAPS pays the Department of Justice and Correctional Services (DOJ\&CS) for the services of the State Attorney. This includes defending claims for civil damages before the courts or through out-of-court settlements. Legal fees paid to the DOJ\&CS also include legal costs that are due to plaintiffs, following court orders and settlements. ${ }^{29}$ These additional costs to the tax-payer have to be factored in when calculating the overall cost of civil claims. The annual reports do not contain itemised information on the cost of legal counsel and other legal services specifically in relation to civil claims. Only overall legal costs are reported on.

A parliamentary reply from the minister of police indicated that just under R570 million had been spent by the SAPS on legal costs relating to civil claims between 2011/12 and 2013/14. ${ }^{30}$ As shown in Table 3 below, in the financial years 2011/12 and 2013/14, the legal fees were higher than the actual payments made (keeping in mind that legal fees are incurred in all cases, whether the outcome results in a liability for the SAPS or not).

Table 3: Cost of legal fees for civil claims at original value, $2011 / 12$ to $2013 / 14$

\begin{tabular}{|c|c|c|c|}
\hline $\begin{array}{c}\text { Financial } \\
\text { year }\end{array}$ & $\begin{array}{c}\text { Legal fees for } \\
\text { civil claims, at } \\
\text { original value } \\
\text { ('000) }\end{array}$ & $\begin{array}{c}\text { Total } \\
\text { payments } \\
\text { made, at } \\
\text { original value } \\
\text { ('000) }\end{array}$ & $\begin{array}{c}\text { Total amounts } \\
\text { finalised, at } \\
\text { original value } \\
\text { ('000) }\end{array}$ \\
\hline 2011/12 & R131342 & R 105960 & R 2818 726 \\
\hline 2012/13 & R156 903 & R 187 132 & R 3 021 501 \\
\hline 2013/14 & R280 547 & R 251 192 & R 3 712 152 \\
\hline
\end{tabular}

Source: Parliamentary reply and SAPS annual reports 2011/12 to 2013/14.

This section has outlined the amounts claimed from the SAPS annually for civil claims, the amounts finalised, whether they resulted in the SAPS being financially liable or not, and the amounts that remain pending at the end of each financial year. While claims made annually have drastically increased, the amounts finalised, either through court proceedings or out-of-court settlements, have not followed the same trend, resulting in an ever-mounting backlog of claims that remain pending against the SAPS. 


\section{Reasons for the claims}

It must be noted that reasons for successful claims cannot be analysed without a thorough review of individual cases and an examination of the reasons behind the awarding of damages on a case-bycase basis. This article does not review a sample of individual cases. However, reasons that may lead individuals to bring claims against the SAPS can be inferred from several factors, both directly linked and external to the behaviour of individual SAPS officials.

In 2014, National Police Commissioner of Police, General Riah Phiyega, issued a statement condemning the 'irregular, improper, unlawful and unacceptable conduct by members' that led to civil claims, and exhorted SAPS members to comply with legal requirements regarding arrest and detention. ${ }^{31}$ However, apart from a general reference to 'respect of human rights', there was no clear condemnation of abusive behaviour by police. Also, Phiyega linked civil claims to the individual behaviour of some SAPS members - a few 'bad apples' who do not comply with the law - rather than recognising the systemic failures of law enforcement underpinning the commission of crime by law enforcement officials. ${ }^{32}$

The 2014/15 SAPS annual report linked civil claims to a lack of compliance with rules and regulations, unlawful arrest and detention, as well as the fact that individuals are more aware of their rights. ${ }^{33}$ The same annual report also introduced a new performance target for the SAPS: a reduction of $3.4 \%$ in the number of civil claims instituted against the department (as opposed to amounts claimed). However, the target was not reached since the number of claims increased by $21 \%$ - the amounts claimed against the department increased by $61 \%$, compared to $2013 / 14 .^{34}$

Unlawful police behaviour, and in particular police brutality, certainly constitutes one of the primary reasons for the high volume of claims. ${ }^{35}$ Recruitment choices, poor training, negligent management, lack of leadership, poor command and control, political condonation of police violence and criminal elements in the employ of the SAPS all affect police behaviour. ${ }^{36}$ One could assume that the 2012 amendment to section 49(2) of the Criminal Procedure Act, which authorises the use of deadly force even when the threat of violence is not immediate, has facilitated the use of force by police. ${ }^{37}$ However, this amendment does not seem to have had a direct impact on civil claims made, as the increase in claims or payments made after 2012 follows a general increase already seen in previous years. This said, the legislative amendment may certainly have been one factor explaining the increase post-2012. Police brutality has an obvious impact on civil claims filed against the SAPS, especially considering the fact that there is no clear correlation between other potential reasons (analysed below) and the trends in civil claims.

Other reasons for civil claims include an increase in SAPS personnel, an increase in the number of arrests, an increase in the number of violent protests, and an increase in the number of complaints filed to the Independent Complaints Directorate (ICD) and its successor, the Independent Police Investigative Directorate (IPID).

Between 2002 and 2012 the SAPS drastically increased its personnel, from a staff contingency of 120549 in 2002 to 199345 in 2012. Since then the SAPS staff establishment has again been reduced and stood at 193692 at the end of the 2014/15 financial year. About $80 \%$ of SAPS staff members are police officers, the rest being administrative and support staff. More staff means more encounters between the police and individuals, and potentially more situations that may give rise to a civil claim, especially considering that the massive recruitment drive was to a certain extent conducted at the expense of quality of staff. ${ }^{38}$ Could the increase in claims filed against the SAPS be related to the increase in staff?

Figure 3 on the next page shows that the ratio of amounts claimed annually (at current rand value) against the number of police officers has increased in recent years. ${ }^{39}$ If there had been a direct correlation between the two, the ratio would have remained relatively stable. But in 2007/08 the average value of each claim per SAPS staff member was R16 848 (at current rand value), increasing to R63 527 in 2014/15. The average claim incurred annually per staff member has more than tripled in eight years. 
Figure 3: Average value of each claim filed per police official, 2007/08 to 2014/15

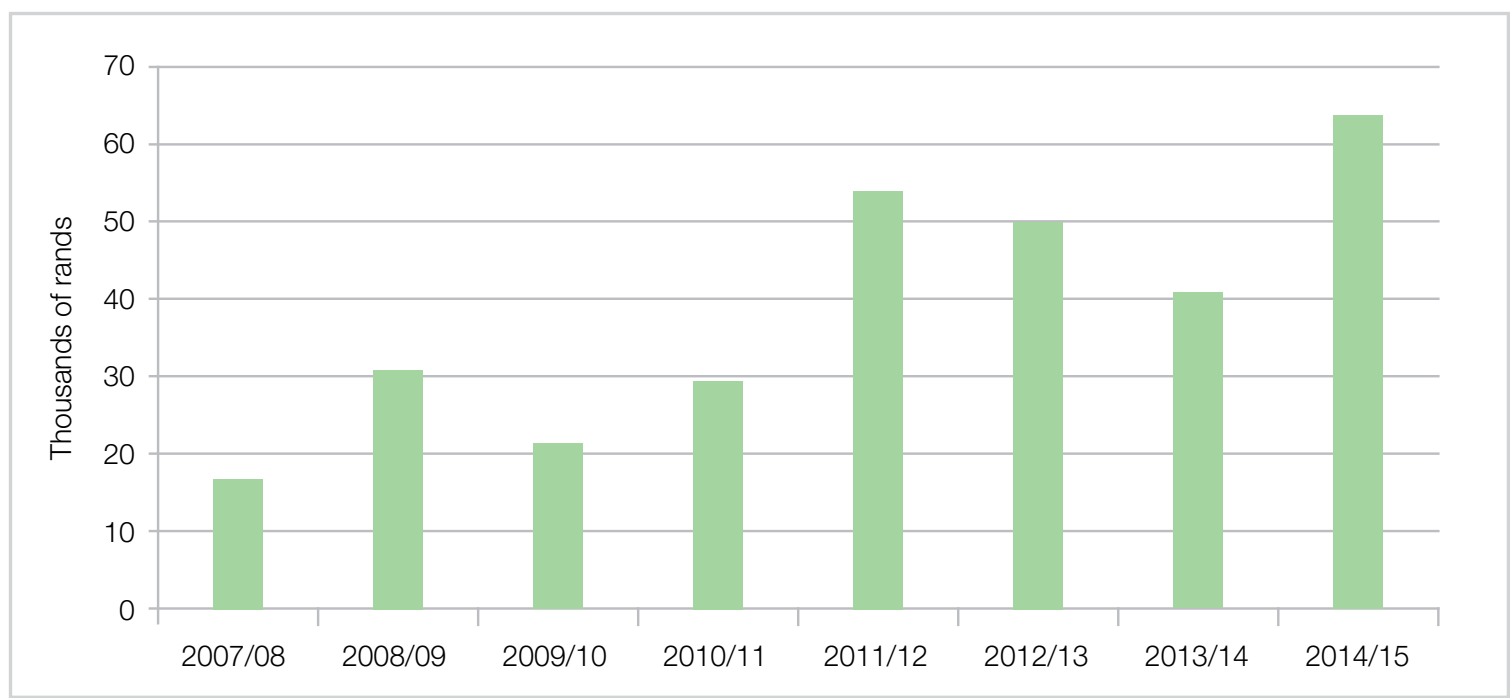

The value of claims made against the SAPS therefore increased faster than the number of police officials in the employ of the SAPS.

The next factor to consider is the number of arrests. As noted in the National Commissioner's 2014 statement and in the 2014/15 SAPS annual report, unlawful arrests and police detention create the potential for a high volume of claims. ${ }^{40}$ This raises the question whether the increase in civil claims might follow the increase in arrests conducted by the SAPS.

However, as shown in Figure 4, there is no clear correlation between the two. The pattern of claims incurred (at current rand value) does not follow the pattern of the overall arrests made by the SAPS on an annual basis. On the contrary, the two spikes in civil claims (between 2010/11 and 2011/12 and between 2013/14 and 2014/15) are not reflected in a similar variation in the number of arrests. This would suggest that the SAPS's reading of the causes for the increase in claims is at least partially erroneous. There are, however, major discrepancies in the data sets for the last two financial years. ${ }^{41}$

Another factor that might explain the increase in civil claims is the number of violent protests to which the

Figure 4: Comparison between total claims incurred by the SAPS, at current rand value, and the number of arrests performed by the SAPS, 2007/08 to 2014/15

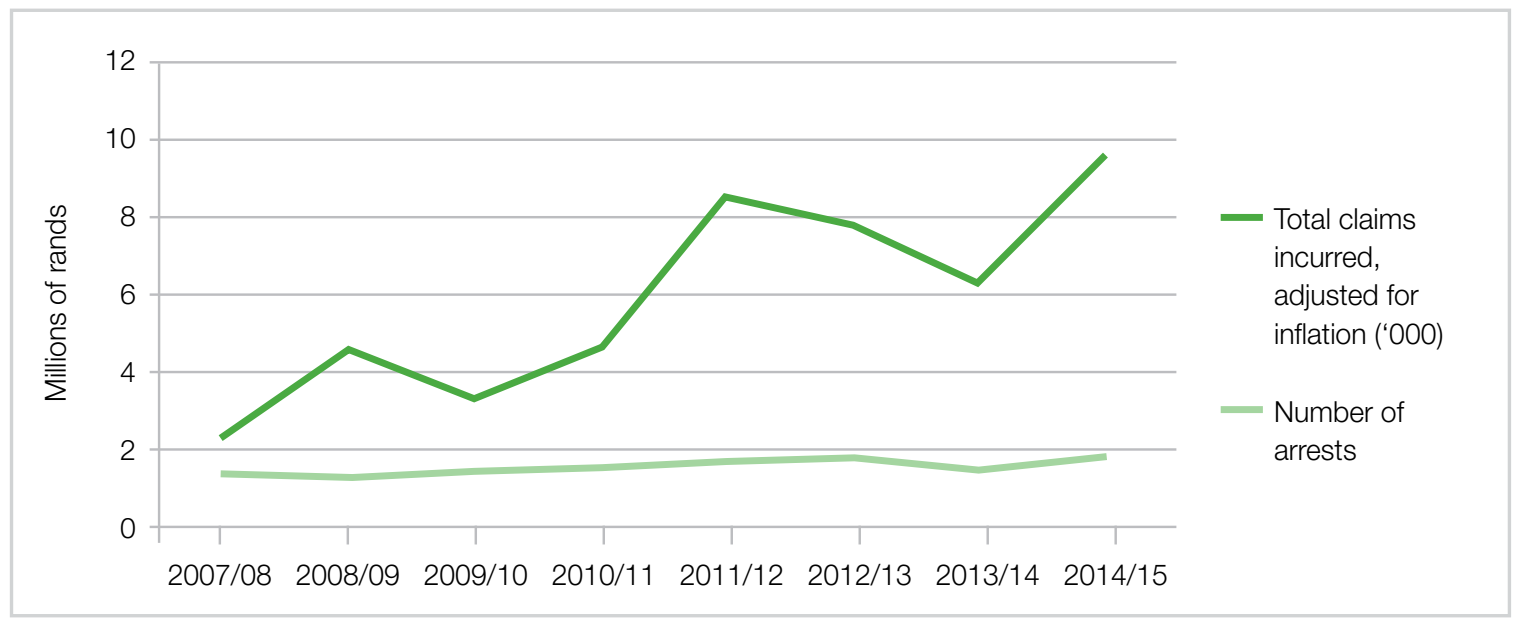


SAPS has had to respond. Indeed, violent protests that result in the use of excessive force by the police increase the potential for a civil claim.

Figure 5 outlines the variation in the number of claims filed against the SAPS from one year to the next (expressed in percentages) and the variation in the number of violent protests to which the SAPS responded (expressed in percentages). ${ }^{42}$ If the column is above $100 \%$, it means that there was an increase in the following year. If the column is under $100 \%$, it means that there was a decrease in the following year. Figure 5 shows that there is no clear correlation between civil claims made and responses to violent protests, since the variations do not follow each other.

The data on the number of arrests and violent protests provide an insight into the socio-economic profile of plaintiffs pursuing claims for civil damages. Indeed, it can be inferred that arrests in South Africa mostly target poor people, one indicator being that the majority of arrests are for non-priority crimes (less serious than shoplifting). ${ }^{43}$ Secondly, violent protests are often triggered by frustration at a lack of service delivery in poor areas. Since there is no correlation between civil claims on the one hand and the number of arrests or the number of violent protests on the other (the latter two mostly involving the poor), it may be inferred that the poor are not those filing civil claims for damages. This is possibly due to the cost of civil proceedings, for which no legal aid is available. ${ }^{44}$

Another possible correlation is between the number of civil claims filed against the SAPS and the number of complaints filed with the ICD (until 2012) and the IPID (from 2012), the civilian oversight body mandated to receive complaints of police misconduct or criminal activity and investigate them. IPID's powers were reinforced compared to those of the ICD, but its mandate was also changed to focus on the most serious crimes allegedly committed by SAPS members, and no longer includes police misconduct. ${ }^{45}$

If plaintiffs were filing civil claims for damages as well as laying complaints with IPID, the two data sets would follow the same trend. However, as shown in Figure 6, this is not the case. During the eight-year period under review, the overall number of complaints recorded by the ICD/IPID have oscillated between 4923 (in 2011/12) and 6728 (in 2012/13). ${ }^{46}$ The data from civil claims to a certain extent confirm this, with 2012/13 recording the highest number of complaints, but seeing lower numbers of civil claims filed in the two years thereafter. Important to note is the major discrepancy in figures available for 2013/14. ${ }^{47}$ Since 2010/11, the overall number of civil claims filed has been much higher than the number of complaints filed with IPID, with IPID recording less than half the

Figure 5: Variation in the number of violent protest incidents to which the SAPS responded and in the total civil claims against the SAPS, variation between two subsequent years, 2009/10 - 2014/15

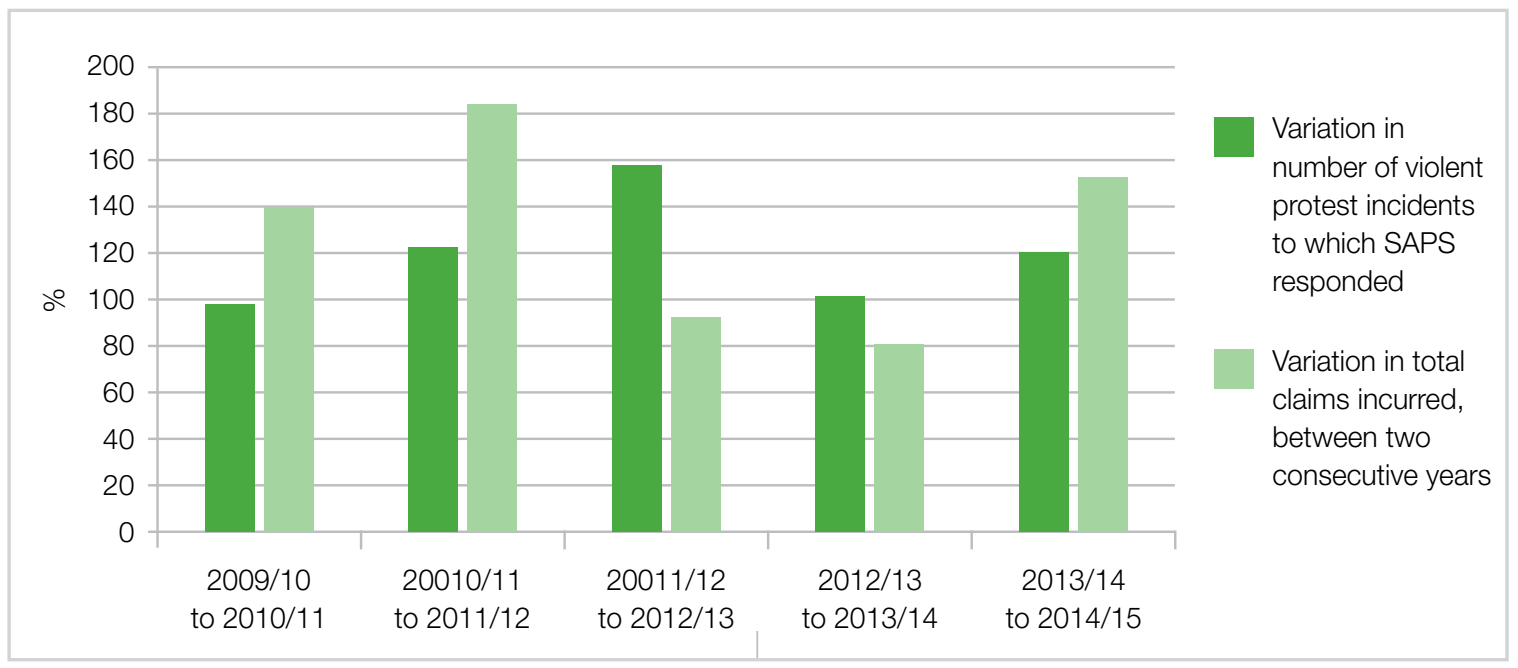


total number of civil claims filed against the SAPS in $2011 / 12$. This seems to suggest that IPID suffers from a crisis of legitimacy, and that individuals prefer going the route of civil claims rather than referring their complaints to IPID. ${ }^{48}$ These figures also seem to show that data on civil claims may provide a more accurate picture of the extent of police criminality than the number of IPID complaints, the former having been much higher than the latter in recent years. This said, one must keep in mind that a plaintiff may file a civil claim for police misconduct that cannot be dealt with by IPID, such as unlawful arrests or unlawful detention, and that the socioeconomic profile of claimants for civil damages and of complainants to IPID may be different.

As noted above, in practice individual police officials are not held financially accountable for the liabilities they cause by their unlawful behaviour. In addition, Muntingh and Dereymaeker found that law enforcement officials enjoy de facto impunity for illegal acts they commit, in that the vast majority of officials are neither adequately internally disciplined nor prosecuted for their illegal behaviour. While large volumes of complaints are recorded by the ICD/IPID, and criminal prosecutions are recommended to the National Prosecuting Authority (NPA), in the past five years less than $15 \%$ of such recommendations resulted in prosecutions. About 3\% of ICD/IPID recommendations resulted in a conviction and a sentence of imprisonment without the option of a fine. ${ }^{49}$ Without financial, disciplinary or criminal accountability, police officers know that their unlawful behaviour will most likely remain unpunished.

\section{Conclusion}

The amounts claimed against the SAPS in civil litigation by individuals have drastically increased over the years, and culminated in claims amounting to more than R9 billion in the 2014/15 financial year. These large claims have affected the public perception of police behaviour, and it would take a drastic reduction in claims to restore confidence in the police and convince the South African public that police brutality and other misconduct is on the decrease.

However, claims that remain pending at the end of a financial year - and are accumulating - seem to be the biggest challenge faced by the SAPS. Pending claims in civil litigation at the end of the 2014/15 financial year stood at more than R26 billion, more than a third of the SAPS budget. It appears that the SAPS is unable or unwilling to influence the speedy finalisation of claims, either through court orders or out-of-court settlements, resulting in either payment or non-payment, with the result that the backlog is mounting, although figures from the latest annual report may be indicating a change.

Furthermore, payments made by the SAPS have drastically increased over the years. In total, and

Figure 6: Number of civil claims filed against the SAPS vs number of complaints recorded by IPID, $2007 / 08$ to $2014 / 15$

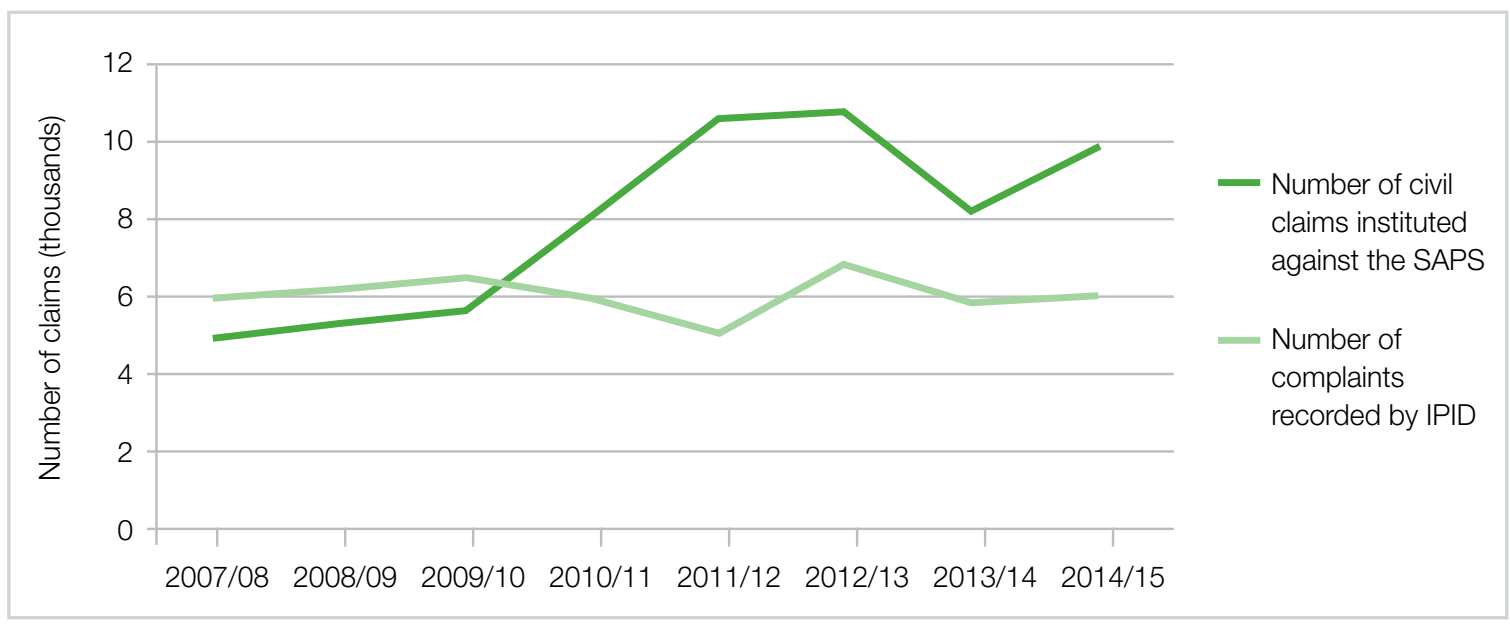


over the eight years under review in this article, $\mathrm{R} 1$ billion was spent compensating victims of police misconduct or criminal behaviour. However, the vast majority of claims that are finalised result in the SAPS not being financially liable, indicating that many claims are either unsubstantiated or grossly inflated.

The question must be asked whether it has not become a 'business' to sue the SAPS. It may be that many people arrested by police officials immediately assume that the officials' behaviour was illegal. Such sentiment is fuelled by the general lack of legitimacy of and confidence in the police in South Africa. ${ }^{50}$ However, the reaction to sue also affects police morale, and confirms that the police enjoy little public support in the execution of their mandate.

Attempting to understand the reasons behind the filing of civil claims, this article found no direct correlation between claims and the increase in SAPS personnel, the number of arrests, the number of violent protests or the number of complaints made to IPID. Furthermore, the fact that civil claims are much higher than complaints to IPID indicates that IPID suffers from a crisis of legitimacy. This lack of correlation suggests that the main reason for civil claims is indeed unlawful police behaviour, be it unlawful arrests and detention or police brutality, to name a few. Some were identified by the SAPS itself. The fact that police officials enjoy de facto financial, disciplinary and prosecutorial impunity for their behaviour has an impact on their future conduct, as it is unlikely that they will be required to answer for their misdeeds.

To comment on this article visit http://www.issafrica.org/sacq.php

\section{Notes}

1 Questions to the minister, written reply by Minister of Police Nathi Mthethwa to question no. 944, internal question paper no. 10-2014, September 2014, https://pmg.org.za/question_ reply/490/ (accessed 30 March 2015).

2 City Press, Phiyega must avert civil claims against cops Mthethwa, 12 March 2013, http://www.news24.com/Archives/ City-Press/Phiyega-must-avert-civil-claims-against-copsMthethwa-20150429 (accessed 3 September 2015); SAPS Journal online, Riah Phiyega, Members must avoid incidents that could result in civil claims, Organisational communication, 25 February 2014, http://www.sapsjournalonline.gov.za/ dynamic/journal_dynamic. aspx?pageid=414\&jid=40623 (accessed 9 September 2015).
3 South African Police Service (SAPS), 2014/15 Annual report, Pretoria, 71, 122.

4 SAPS, 2014/15 Annual report, 122.

5 Max Loubser, Law of delict, in CG van der Merwe and Jacques du Plessis (eds), Introduction to the law of South Africa, The Hague: Kluwer Law International, 2004, 275-315.

6 State Liability Act of 1957 (Act 20 of 1957), section 1; Cerita Joubert, Applied law for police officials, Claremont: Juta Law, 2001, 26. A court will have to rule on the extent of the state's liability as per the portion of its fault, as per the Apportionment of Damages Act of 1956 (Act 34 of 1956), section 2.

7 See, for example, Leo Boonzaier, State liability in South Africa: a more direct approach, South African Law Journal, 2, 2013, 330; and Heidi Barnes, F v Minister of Safety and Security: vicarious liability and state accountability for the criminal acts of police officers, South African Crime Quarterly, 47, 2014, 29.

8 Public Finance Management Act of 1999 (Act 1 of 1999), section 76(1)(h).

9 Treasury Regulations, section 12.2.1. See also section 12.7.3.

10 Joubert, Applied law for police officials, 26.

11 Treasury Regulations, sections 12.2.1, 12.5, 12.7.1.

12 Ibid., sections 12.5, 12.7.1, 12.7.3.

13 Questions to the minister, Written reply by Minister of Police Nathi Mthethwa to question no. 1661, Internal question paper no. 22-2013, 6 August 2013, https://pmg.org.za/question_ reply/461/ (accessed 30 March 2015). See also Questions to the minister, Written reply by Minister of Police Nathi Mthethwa to question no. 659, reply no. 36/1/4/1/201100297, 13 December 2011, https://pmg.org.za/question_reply/288/ (accessed 30 March 2015), in which the minister clarified the legal basis under which officials can be held individually liable for damages paid following a successful civil claim in delict against the minister of police.

14 Contingent liabilities are defined as 'a possible obligation that arises from past events, and whose existence will be confirmed only by the occurrence or non-occurrence of one or more uncertain future events not within the control of the department or when there is a present obligation that is not recognised because it is not probable that an outflow of resources will be required to settle the obligation or the amount of the obligation cannot be measured reliably'. See SAPS, 2013/14 Annual report, 302.

15 SAPS, 2007/08 Annual report, 218; SAPS, 2008/09 Annual report, 216; SAPS, 2009/10 Annual report, 190; SAPS, 2010/11 Annual report, 190; SAPS, 2011/12 Annual report, 200; SAPS, 2012/13 Annual report, 257; SAPS, 2013/14 Annual report, 336; SAPS, 2014/15 Annual report, 416; Questions to the minister, Written reply by Minister of Police Nathi Mthethwa to question no. 644, reply no. 201136/1/4/1/201300073, 16 April 2013, http:// www.politicsweb.co.za/documents/10-552-claims-forr71bn-instituted-against-saps-in (accessed 30 November 2015); Questions to the minister, Written reply by Minister of Police Nkosinathi Nhleko to question no. 502, reply no. 36/1/4/1/201500067, 26 March 2015, unpublished. 


\begin{tabular}{|c|c|c|c|}
\hline $\begin{array}{c}\text { Financial } \\
\text { year }\end{array}$ & $\begin{array}{l}\text { Total claims } \\
\text { paid out - as } \\
\text { reported in } \\
\text { annual reports }\end{array}$ & $\begin{array}{l}\text { Total claims } \\
\text { paid out - as } \\
\text { reported in } \\
\text { the April } 2013 \\
\text { parliamentary } \\
\text { reply }\end{array}$ & $\begin{array}{l}\text { Total claims } \\
\text { paid out - as } \\
\text { reported } \\
\text { in the } \\
\text { March } 2015 \\
\text { parliamentary } \\
\text { reply }\end{array}$ \\
\hline $2007 / 08$ & R 38207000 & R165 558000 & \\
\hline $2008 / 09$ & R 57403000 & R145 620000 & \\
\hline $2009 / 10$ & R 79451000 & R162 783000 & \\
\hline $2010 / 11$ & R 85605000 & R149 264000 & \\
\hline $2011 / 12$ & R105 960000 & R 93120000 & R134 836021 \\
\hline $2012 / 13$ & R187 132000 & & R209 926037 \\
\hline $2013 / 14$ & R251 192000 & & R296 500333 \\
\hline
\end{tabular}

16 Each year, the SAPS adjusts its closing balances of the previous year, based on data that were not available at the time the audit was compiled. This means that the 2013/14 annual report will contain an opening balance (which is the same as the 2012/13 closing balance) as well as an adjusted opening balance. This paper uses the adjusted figures.

17 Using Statistics SA's annual inflation rates. See Statistics SA, CPI headline index numbers, http://www.statssa.gov.za/ publications/P0141/CPIHistory.pdf (accessed 2 September 2015).

18 The figures used here of pending claims, or closing balances, are those based on adjustments made by the SAPS in the following year's annual report.

19 These amounts include adjustments to prior year balances as reflected in annual reports.

20 SAPS, 2007/08 Annual report, 218; SAPS, 2008/09 Annual report, 216; SAPS, 2009/10 Annual report, 190; SAPS, 2010/11 Annual report, 190; SAPS, 2011/12 Annual report, 200; SAPS, 2012/13 Annual report, 257; SAPS, 2013/14 Annual report, 336; SAPS, 2014/15 Annual report, 416.

21 See, for example, Mandy de Waal, The expensive side of police brutality and recklessness, The Daily Maverick, 16 July 2012, http://www.dailymaverick.co.za/article/2012-0716-the-expensive-side-of-police-brutality-and-recklessness/ (accessed 3 September 2015); Diane Kohler-Barnard, SAPS' R21 billion contingent liability projection must now be capped, DA News, 2 October 2014, https://www.da.org.za/2014/10/ saps-r21-billion-contingent-liability-projection-must-nowcapped/ (accessed 3 September 2015).

22 In 2007/08, the SAPS's annual budget was R36.4 billion. In 2014/15, its annual budget was R72.5 billion.

23 For example, in his March 2015 parliamentary reply, the minister of police indicated that he had budgeted R312 million for the payment of claims in 2015/16, despite accumulative claims pending at the end of 2014/15 sitting at R26.9 billion. See Written reply by Minister of Police Nkosinathi Nhleko to question no. 502.

24 Col Tumi Shai, SAPS explains R11bn liability figure, SAPS press statement, 10 October 2011, http://www.politicsweb. co.za/archive/saps-explains-r11 bn-liability-figure (accessed 9 September 2015).

25 Uniform Rules of Court, Rule 34; Magistrates Courts' Rules of Court, Rule 18; South African Law Commission, Simplification of criminal procedure (out-of-court settlements in criminal cases), Discussion Paper 100, Project 73, 5, 28-30.

26 Greg Nicolson, Marikana: Another delay and a hint of compensation, The Daily Maverick, 15 September 2015, http://www.dailymaverick.co.za/article/2015-09-15-marikanaanother-delay-and-a-hint-of-compensation/ (accessed 15 September 2015).

27 Again, it is unclear whether most claims result in a finding in the SAPS's favour, or whether most claims result in a finding in favour of the plaintiff, but with an order of compensation for a much lower amount than what the plaintiff originally claimed, or a combination of both.

28 SAPS, 2007/08 Annual report, 218; SAPS, 2008/09 Annual report, 216; SAPS, 2009/10 Annual report, 190; SAPS, 2010/11 Annual report, 190; SAPS, 2011/12 Annual report, 200; SAPS, 2012/13 Annual report, 257; SAPS, 2013/14 Annual report, 336; SAPS, 2014/15 Annual report, 416.

29 Written reply by Minister of Police Nkosinathi Nhleko to question no. 502.

30 Written reply by Minister of Police Nkosinathi Nhleko to question no. 502; 2011/12 Annual report, 200; SAPS, 2012/13 Annual report, 257; SAPS, 2013/14 Annual report, 336.

31 Phiyega, Members must avoid incidents that could result in civil claims.

32 Lukas Muntingh and Gwénaëlle Dereymaeker, Understanding impunity in the South African law enforcement agencies, Civil Society Prison Reform Initiative (CSPRI), Research Report, Bellville: Community Law Centre, 2013, 23.

33 SAPS, 2014/15 Annual report, 71, 122.

34 Ibid., 71, 127, 416. The same annual report indicated that managers would be held accountable for a reduction (or increase) in civil claims instituted, through their performance agreements.

35 See for example, De Waal, The expensive side of police brutality and recklessness, which links police brutality and civil claims, but only speaks about claims made and not actual liabilities.

36 Institute for Security Studies (ISS) and University of South Africa (UNISA) seminar, Understanding police brutality in South Africa: challenges and solutions, UNISA, 11 April 2013. The most notorious example of political condonation was when Deputy Minister of Safety and Security Susan Shabangu, when addressing a group of police officers, said that they must shoot to kill 'the bastards', referring to criminals (speaking at an anti-crime rally in Pretoria on 9 April 2008). For more examples of political rhetoric facilitating the abuse of force by police, see Muntingh and Dereymaeker, Understanding impunity in the South African law enforcement agencies, 25-28.

37 David Bruce, Beyond Section 49: control of the use of lethal force, South African Crime Quarterly, 36, 2011, 3.

38 David Bruce, New blood: implications of en masse recruitment for the South African Police Service, South African Crime Quarterly, 43, 2013, 17.

39 SAPS, 2007/08 Annual report, xv; SAPS, 2008/09 Annual report, xvi; SAPS, 2009/10 Annual report, xv; SAPS, 2010/11 Annual report, iv; SAPS, 2011/12 Annual report, iv; SAPS, 2012/13 Annual report, 12; SAPS, 2013/14 Annual report, 31; SAPS, 2014/15 Annual report, 308.

40 Phiyega, Members must avoid incidents that could result in civil claims; SAPS, 2014/15 Annual report, 71, 122. 
41 SAPS, 2007/08 Annual report, 84; SAPS, 2008/09 Annual report, 73; SAPS, 2009/10 Annual report, 87; SAPS, 2010/11 Annual report, 66; SAPS, 2011/12 Annual report, 66; SAPS, 2012/13 Annual report, 77; SAPS, 2013/14 Annual report, 107; SAPS, 2014/15 Annual Report, 141-142. This chart uses the number of arrests for 2013/14 as reported in the 2013/14 annual report (1 392856 arrests). However, the 2014/15 annual report states that the SAPS effected 1820846 arrests in 2013/14. Also, the 2014/15 contains two figures for arrests. The general table on arrests reports that 1707654 arrests were made (pp. 141-142). However, other parts of the annual report state that the SAPS arrested 1660833 people in 2014/15 (pp. 132, 150-151). The reasons for the discrepancies are unclear. The 2014/15 figures may be explained by the fact that the first figure refers to 'arrests' and the second to 'arrests and charges'. It is unclear whether the number of arrests reported on in the annual reports includes arrests that do not lead to a charge. These scenarios in particular may amount to unlawful arrest and detention and therefore a civil claim. If arrests that do not lead to a charge are never reported on in annual reports, it may explain why there is no correlation between the number of arrests and the amount of civil claims made against the SAPS.

42 SAPS, 2009/10 Annual report, 94; SAPS, 2010/11 Annual report, 78; SAPS, 2011/12 Annual report, 84; SAPS, 2012/13 Annual report, 101; SAPS, 2013/14 Annual report, 141; SAPS, 2014/15 Annual Report, 182.

43 SAPS, 2007/08 Annual report, 84; SAPS, 2008/09 Annual report, 73; SAPS, 2009/10 Annual report, 87; SAPS, 2010/11 Annual report, 66; SAPS, 2011/12 Annual report, 66; SAPS, 2012/13 Annual report, 77; SAPS, 2013/14 Annual report, 107; SAPS, 2014/15 Annual Report, 141-142.

44 Although Legal Aid South Africa does not rule out the provision of legal assistance in civil cases, it states that as a priority it provides legal assistance in criminal cases.

45 Julie Berg, Civilian oversight of police in South Africa: from the ICD to the IPID, Police Practice and Research, 2013, 144-154.

46 The latter reflects the first year of the Independent Police Investigative Directorate's (IPID) operation, and was followed by a dip in the number of complaints recorded in the following year. See Independent Complaints Directorate (ICD), 2009/10 Annual report, 69-130; ICD, 2010/11 Annual report, 28-45; IPID, 2011/12 Annual report, 25-41; IPID, 2012/13 Annual report, 15-68; IPID, 2013/14 Annual report, 27; IPID, 2014/15 Annual report, 43.

47 All data on the number of civil claims filed comes from a parliamentary reply, which reported that 10434 civil claims had been filed in 2013/14. However, the SAPS's 2014/15 annual report stated that 8161 civil claims had been filed in $2013 / 14$. The reason for the discrepancy is unclear. The data used in Figure 6 is that taken from the annual report. See Written reply by Minister of Police Nkosinathi Nhleko to question no. 502; and SAPS, 2014/15 Annual Report, 122.

48 It is unclear whether those filing a civil claim have also filed a complaint with the IPID. The two categories of plaintiffs may be entirely different.

49 Muntingh and Dereymaeker, Understanding impunity in the South African law enforcement agencies.

50 Johan Burger, To protect and to serve: restoring public confidence in the police, South African Crime Quarterly, 36, 2011, 13-22. 